\title{
Imperial Mecca
}

COLUMBIA STUDIES IN INTERNATIONAL AND GLOBAL HISTORY 


\section{COLUMBIA STUDIES IN INTERNATIONAL AND GLOBAL HISTORY}

Cemil Aydin, Timothy Nunan, and Dominic Sachsenmaier, Series Editors

This series presents some of the finest and most innovative work coming out of the current landscapes of international and global historical scholarship. Grounded in empirical research, these titles transcend the usual area boundaries and address how history can help us understand contemporary problems, including poverty, inequality, power, political violence, and accountability beyond the nation-state. The series covers processes of flows, exchanges, and entanglements-and moments of blockage, friction, and fracturenot only between "the West" and "the Rest" but also among parts of what has variously been dubbed the "Third World" or the "Global South." Scholarship in international and global history remains indispensable for a better sense of current complex regional and global economic transformations. Such approaches are vital in understanding the making of our present world.

Cemil Aydin, The Politics of Anti-Westernism in Asia: Visions of World Order in Pan-Islamic and Pan-Asian Thought

Adam M. McKeown, Melancholy Order: Asian Migration and the Globalization of Borders Patrick Manning, The African Diaspora: A History Through Culture James Rodger Fleming, Fixing the Sky: The Checkered History of Weather and Climate Control Steven Bryan, The Gold Standard at the Turn of the Twentieth Century: Rising Powers, Global Money, and the Age of Empire

Heonik Kwon, The Other Cold War

Samuel Moyn and Andrew Sartori, eds., Global Intellectual History Alison Bashford, Global Population: History, Geopolitics, and Life on Earth Adam Clulow, The Company and the Shogun: The Dutch Encounter with Tokugawa Japan Richard W. Bulliet, The Wheel: Inventions and Reinventions

Simone M. Müller, Wiring the World: The Social and Cultural Creation of Global Telegraph Networks

Will Hanley, Identifying with Nationality: Europeans, Ottomans, and Egyptians in Alexandria Perin E. Gürel, The Limits of Westernization: A Cultural History of America in Turkey Dominic Sachsenmaier, Global Entanglements of a Man Who Never Traveled: A SeventeenthCentury Chinese Christian and His Conflicted Worlds

Perrin Selcer, The UN and the Postwar Origins of the Global Environment: From World Community to Spaceship Earth

Ulbe Bosma, The Making of a Periphery: How Island Southeast Asia Became a Mass Exporter of Labor

Raja Adal, Beauty in the Age of Empire: Japan, Egypt, and the Global History of Aesthetic Education Mona L. Siegel, Peace on Our Terms: The Global Battle for Women's Rights After the First World War Nicole CuUnjieng Aboitiz, Asian Place, Filipino Nation: A Global Intellectual History of the Philippine Revolution, 1887-1912 


\section{IMPERIAL MECCA}

Ottoman Arabia and the Indian Ocean Hajj

MICHAEL CHRISTOPHER LOW

COLUMBIA UNIVERSITY PRESS NEW YORK 


\section{Columbia University Press}

Publishers Since 1893

New York Chichester, West Sussex

cup.columbia.edu

Copyright @ 2020 Columbia University Press

All rights reserved

Library of Congress Cataloging-in-Publication Data

Names: Low, Michael Christopher, author.

Title: Imperial Mecca : Ottoman Arabia and the Indian Ocean hajj / Michael Christopher Low. Description: New York : Columbia University Press, 2020. | Series: Columbia studies in international and global history | Includes bibliographical references and index.

Identifiers: LCCN 2020001931 (print) | LCCN 2020001932 (ebook) | ISBN 9780231190763 (cloth) |

ISBN 9780231190770 (paperback) | ISBN 9780231549097 (ebook)

Subjects: LCSH: Muslim pilgrims and pilgrimages-Saudi Arabia-Mecca. |

Muslim pilgrims and pilgrimages-Indian Ocean Region. | Hejaz (Saudi Arabia)-History. |

Great Britain-Relations-Saudi Arabia. | Saudi Arabia-Relations-Great Britain. |

Great Britain-Foreign relations-Turkey. | Turkey-Foreign relations-Great Britain.

Classification: LCC BP187.3 .L69 2020 (print) | LCC BP187.3 (ebook) | DDC 297.3/524-dc23

LC record available at https://lccn.loc.gov/2020001931

LC ebook record available at https://lccn.loc.gov/2020001932

Columbia University Press books are printed on permanent and durable acid-free paper.

Printed in the United States of America

Cover image: Panoramic View of the City of Mecca, by Shawkat/Şevket. Turkey, dated 1341 A.H. (1922-1923). Khalili Family Trust, the Khalili Collections,

Hajj and the Arts of Pilgrimage (700-2000), MSS 1163.

Cover design: Chang Jae Lee 
For Cari, Annabelle, and Josie 
